\title{
Analisis Yuridis Penghentian Penyidikan terhadap Tindak Pidana Korupsi Ditreskrimsus Polda Sumatera Utara
}

\section{Juridical Analysis of the Cessation of Investigation of the Corruption Crimes of North Sumatra Regional Police}

\author{
Rusdi*, Mahmud Mulyadi \& Ibnu Affan \\ Program Studi Magister Hukum, Fakultas Hukum \\ Universitas Islam Sumatera Utara, Indonesia
}

Diterima: 14 Februari 2020; Disetujui: 28 Maret 2020; Dipublish: 28 April 2020

*Coresponding Email: rusdirusdi@gmail.com

\begin{abstract}
Abstrak
Tujuan penelitian ini mengenai pengaturan penghentian penyidikan, Implikasi yuridis dan Hambatan pelaksanaan penghentian penyidikan terhadap tindak pidana korupsi yang dilakuakn oleh penyidik Polisi di Ditreskrim Polda Sumut. Jenis penelitian ini adalah penelitian yuridis empiris. Sifat penelitian bersifat deskriptif analisis. Penelitian ini menggunakan beberapa pendekatan, yaitu pendekatan undang-undang dan konseptual. Jenis dan sumber data penelitian terdiri dari data primer dan sekunder. Adapun analisis data yang digunakan dalam penelitian ini yaitu analisis data kualitatif. Berdasarkan hasil penelitian diperoleh, pengaturan penghentian penyidikan terhadap tindak pidana korupsi mengacu pada KUHAP yang didasari pada tiga alasan, yaitu tidak tedapat cukup bukti, perbuatan tersebut tidak termasuk dan demi hukum. Penghentian penyidikan dalam perkara tindak pidana korupsi dominan karena tidak terdapat cukup bukti. Implikasi yuridis terhadap penghentian penyidikan terhadap tindak pidana korupsi karena tidak cukup bukti, maka penghentian penyidikan dapat bersifat sementara ataupun selamanya. Hambatan dalam pelaksanaan penghentian penyidikan terhadap tindak pidana korupsi adalah adanya anggapan dari masyarakat bahwa penghentian penyidikan didasari pada penyimpangan kewenangan yang dilakukan oleh penyidik. Sehingga, hal ini menjadi hambatan tersendiri bagi penyidik dalam memutuskan penghentian penyidikan terhadap perkara tindak pidana korupsi yang sedang ditanganinya.

Kata Kunci: Penghentian, Penyidikan, Tindak Pidana Korupsi.
\end{abstract}

\begin{abstract}
The purpose of this study regarding the arrangement of the cessation of investigations, juridical implications and barriers to the implementation of the cessation of investigations of criminal acts of corruption carried out by police investigators in the North Sumatra Regional Police. This type of research is empirical juridical research. The nature of the study is descriptive analysis. This research uses several approaches, namely the law and conceptual approach. Types and sources of research data consist of primary and secondary data. The data analysis used in this study is qualitative data analysis. Based on the results of the study obtained, the arrangement for stopping the investigation of criminal acts of corruption refers to the Criminal Procedure Code which is based on three reasons, namely that there is insufficient evidence, the act is not included and by law. Stopping investigations in corruption cases is dominant because there is not enough evidence. Juridical implications for the cessation of investigations of criminal acts of corruption due to insufficient evidence, the cessation of investigations can be temporary or forever. The obstacle in carrying out the cessation of the investigation of corruption is the assumption of the public that the cessation of the investigation is based on deviations of authority by the investigator. Thus, this has become a special obstacle for investigators in deciding to stop investigating cases of corruption which are being handled.
\end{abstract}

Keywords: Termination, Investigation, Corruption Crime.

How to Cite: Rusdi, Mulyadi, M. \& Affan, I. (2020). Analisis Yuridis Penghentian Penyidikan terhadap Tindak Pidana Korupsi Ditreskrimsus Polda Sumatera Utara. Journal of Education, Humaniora and Social Sciences (JEHSS). 2 (3): 720-734. 


\section{PENDAHULUAN}

Tindak pidana korupsi di Indonesia telah menjadi suatu fenomena yang sejak dulu sulit dibantah dengan argumentasi apapun. Perilaku menyimpang itu tidak saja telah berlangsung secara sistematis, dan bersifat institusional, melainkan juga telah masuk ke dalam wilayah institusi peradilan pidana yang semestinya berdiri sebagai "tiang penyangga". Fenomena korupsi telah menimbulkan ketidakpercayaan publik terhadap hukum dan sistem peradilan pidana, dan dikhawatirkan dapat mengakibatkan disfungsionalisasi hukum pidana (Danil, 2011).

Korupsi merupakan masalah serius dan tergolong dalam tindak pidana yang dapat membahayakan stabilitas dan keamanan masyarakat, membahayakan pembangunan sosial ekonomi, juga politik, serta merusak nilai-nilai demokrasi dan moralitas. Karena lambat laun perbuatan ini seakan menjadi sebuah budaya, sehingga Korupsi menjadi ancaman terhadap pencapaian cita-cita bangsa, yaitu menuju masyarakat adil dan Makmur (Hartanti, 2012). Kejahatan korupsi tergolong sebagai kejahatan luar biasa "extra ordinary crime", sehingga untuk penanggulangan dan pemberantasan tindak pidana korupsi dibutuhkan upaya dan sarana yang esktra (extra ordinary instrumet). Upaya penangulangan maupun pemberantasannya tidak dapat lagi dilakukan secara biasa, tetapi dengan cara-cara yang luar biasa (Extra ordinary Counter Measures) (Mulyadi, 2013).

Menyadari begitu besarnya dampak dari kejahatan korupsi dan begitu kompleksnya masalah korupsi di tengah-tengah krisis multi dimensional di Indonesia, telah menjadikan korupsi sebagai bentuk isu yang krusial dan sebagai bentuk ancaman baru bagi bangsa dan negara Indonesia.

Praktik korupsi yang terjadi disemua aspek kehidupan masyarakat, dapat dikatakan telah menjadi ancaman bagi budaya bangsa. Bagaimana tidak, korupsi di Indonesia telah menjadi bagian budaya masyarakat Indonesia. Di samping itu, praktek korupsi diyakini tidak saja menimbulkan kerugian keuangan dan perekonomian negara, tetapi juga berdampak pada pertumbuhan dan keberlangsungan pembangunan nasional yang menuntut efisiensi tinggi. Pada akhirnya, praktek korupsi akan menjadi hambatan bagi bangsa dan negara Indonesia dalam mencapai cita-cita luhur bangsa dan negara Indonesia dalam rangka mewujudkan masyarakat Indonesia yang adil dan makmur, sebagaimana tercantum dalam pembukaan UUD Tahun 1945.

Begitu besarnya dampak dari korupsi, maka masalah korupsi di Indonesia membutuhkan perhatian yang serius dalam pencegahan dan penanggulangannya. Perhatian serius pemerintah dalam menanggulangi masalah korupsi di Indonesia dilaksanakan melalui berbagai kebijakan, mulai dari regulasi hukum (legal substance), pembaharuan lembaga atau struktur hukum (legal structure) dan budaya hukum (legal kulture).

Korupsi sebagai kejahatan luar biasa tentunya membutuhkan upaya yang lebih extra dalam penanggulangan dan pemberantasannya, jika dibandingkan dengan kejahatan biasa (konvensional). Dalam hubungan ini, penerapan konsep "materiel 
wedertelijk", konsep "reversal of the burden of proof" dan pembentukan institusi khusus sebagai "anti korupsi" yang independen menjadi hal penting dan cukup relevan dalam kerangka pemberantasan tindak pidana korupsi (Danil, 2011).

Secara substansial, upaya pemerintah dalam penanggulangan dan pemberantasan korupsi di awali dengan pembentukan aturan hukum yang mengatur tentang kejahatan. Upaya pembentukan aturan hukum (regulasi) kejahatan korupsi diawali dengan perumusan tindak pidana korupsi dalam Undang-Undang Nomor 31 Tahun 1999 Tentang Pemberantasan Korupsi sebagaimana telah diubah dengan Undang-Undang Nomor 20 Tahun 2001 (selanjutnya disingkat dengan Undang-Undang PTPK).

Substansi Undang-Undang PTPK mengisyaratkan bahwa tindak pidana korupsi sebagai kejahatan luar biasa (extra ordinary crime), karenanya dibutuhkan penangangan yang extra melalui pembentukan lembaga khusus pemberantasan tindak pidana korupsi. Sesuai amanat Undang-Undang PTPK, maka pemerintah kemudian membentuk pranata hukum baru yang dikenal dengan istilah Komisi Pemberantasan Tindak Pidana Korupsi (selanjutnya disingkat KPK). KPK memiliki tugas dan wewenang melakukan koordinasi dan supervisi, termasuk melakukan penyelidikan, penyidikan, dan penuntutan sesuai dengan ketentuan peraturan perundang-undangan yang berlaku (Pasal 43 Ayat (2) Undang-Undang Negara Republik Indonesia Nomor 31 Tahun 1999Tentang Pemberantasan Tindak Pidana Korupsi).

Penegakan hukum terhadap kejahatan korupsi memiliki perbedaan dengan penegakan terhadap kejahatan konvensional. Perbedaan tersebut dapat dilihat dari kewenangan penyidikan terhadap tindak pidana korupsi, yang oleh undang-undang diberikan kepada tiga lembaga penegak hukum, yaitu: Kepolisian, Kejaksaan dan KPK.

Pembaharuan hukum pidana dalam penegakan hukum tindak pidana korupsi telah menentukan bahwa kewenangan penyidikan tindak pidana korupsi dimiliki oleh 3 (tiga) lembaga penegak hukum, yaitu Kepolisian, Kejaksaan dan KPK. Masing-masing lembaga memiliki kewenangan untuk melakukan penyidikan tindak pidana korupsi. Wewenang masing-masing lembaga diatur dalam undang- undang tersendiri, sehingga kewenangan dan wewenang masing-masing lembaga penegak hukum tersebut telah memiliki payung hukum (umbrella law).

Langkah awal dari proses penegakan hukum, termasuk penegakan hukum tindak pidana korupsi adalah pelaksanaan penyelidikan dan penyidikan. Pelaksanaan penyelidikan terhadap suatu dugaan tindak pidana dilakukan untuk mencari titik terang dari suatu peristiwa, apakah merupakan tindak pidana atau tidak, sehingga dapat dilanjutkan pada tahap penyidikan. Sedangkan penyidikan terhadap suatu peristiwa atau tindak pidana bertujuan mencari tahu siapa pelaku atau orang yang melakukan tindak pidana tersebut (Harahap, 2009).

Penegakan hukum pidana pada dasarnya merupakan penegakan ketentuan hukum materil dan formil. Demikian pula dalam penegakan hukum tindak pidana korupsi, selain penegakan hukum ketentuan materil, juga meliputi penegakan hukum formil, yaitu tindakan yang akan dilakukan oleh aparat penegak hukum. 
Secara teoritik dan praktik, hukum acara tindak pidana korupsi dapat dikatakan bersifat ganda. Karena, selain mengacu kepada ketentuan acara pada Undang-Undang PTPK sebagai "lex specialist", juga berorentasi pada KUHAP sebagai "lex generalist". Pasal 26 Undang-Undang PTPK, menyebutkan: "penyidikan, penuntutan, dan pemeriksaan di sidang pengadilan terhadap tindak pidana korupsi, dilakukan berdasarkan hukum acara pidana yang berlaku, kecuali ditentukan lain dalam undangundang ini".

Ketentuan Pasal 26 Undang-Undang PTPK mengisyaratkan bahwa hukum acara pidana yang berlaku terhadap tindak pidana korupsi adalah KUHAP, tetapi dalam hal tertentu terdapat pengecualian dari ketentuan umum yang diatur dalam KUHAP, yaitu dengan menggunakan Undang-Undang No. 46 Tahun 2009 Tentang Pengadilan Tindak Pidana Korupsi yang dimaksudkan untuk mempercepat proses peradilan terhadap kasus-kasus atau tindak pidana korupsi.

Proses penyidikan terhadap suatu peristiwa yang diduga merupakan tindak pidana, adakalanya dengan alasan-alasan tertentu prosesnya harus dihentikan. KUHAP menentukan 3 (tiga) alasan dilakukannya penghentian proses penyidikan, yaitu: tidak terdapat cukup bukti, peristiwa tersebut ternyata bukan merupakan tindak pidana, penyidikan dihentikan demi hukum (Pasal 109 ayat (2) Undang-Undang Negara Republik Indonesia Nomor 8 Tahun 1981 Tentang Kitab Undang-Undang Hukum Acara Pidana.). Penghentian penyidikan demi hukum, dapat terjadi karena adanya peristiwa hukum yang terjadi terkait dengan proses penyidikan terhadap perbuatan pidana tersebut, diantaranya: 1. Terdakwa meninggal dunia (Pasal 77 KUHPidana); 2. Perkaranya nebis in idem (Pasal 76 KUHPidana); 3. Perkaranya kedaluwarsa/verjaring (Pasal 78 KUHPidana); 4. Pencabutan perkara yang sifatnya delik aduan (Pasal 75 dan Pasal 284 ayat (4) KUHPidana). KUHAP memberi wewenang penghentian penyidikan bagi penyidik, dengan memberikan wewenang bagi penyidik untuk menghentikan penyidikan yang telah dimulainya (Harahap, 2009).

Penghentian penyidikan terhadap suatu perkara pidana merupakan kewenangan yang dimiliki oleh penyidik dalam menangani suatu perkara pidana. Penghentian penyidikan oleh penyidik akan menimbulkan implikasi hukum, bahwa proses perkara tidak lagi perlu diteruskan pada tahapan penegakan hukum selanjutnya.

KUHAP telah menentukan secara limitatif mengenai alasan-alasan yang dapat digunakan oleh penyidik sebagai dasar untuk menghentikan penyidikan. Penggarisan alasan-alasan penghentian penyidikan tersebut menjadi penting dalam proses peradilan pidana guna menghindari kecenderungan negatif pada diri pejabat penyidik (Harahap, 2009). Hakikatnya KUHAP mengharapkan supaya penggunaan wewenang penghentian penyidikan dilaksanakan sesuai dengan alasan-alasan yang telah ditentukan. Dengan demikian, pelaksanaan wewenang penghentian penyidikan yang diberikan undangundang kepada penyidik tidaklah dapat dilaksanakan dengan sesuka hati. Penghentian penyidikan haruslah sesuai dengan ketentuan yang diatur dalam KUHAP, yaitu didasari pada alasan-alasan yang dapat dipertanggungjawabkan secara hukum. 
Kewenangan penyidikan yang dimiliki oleh penyidik untuk melakukan penyidikan tindak pidana korupsi, karena alasan-alasan tertentu terdapat kemungkinan dilakukan penghentikan penyidikan. Penyidikan terhadap tindak pidana korupsi bukanlah suatu hal yang mudah bagi penyidik, sebab kejahatan korupsi merupakan kejahatan terogranisir (organized crimed) dan dapat pula disebut sebagai (extra ordinary crime) (Mulyadi, 2013).

Penghentian penyidikan oleh penyidik Polisi tentunya akan memiliki implikasi hukum tertentu, baik bagi penyidik maupun orang yang diduga dan ditetapkan sebagai tersangka. Oleh sebab itu, dalam pelaksanaan penghentian penyidikan haruslah dapat dipertanggungjawabkan secara hukum, yaitu sesuai dengan alasan-alasan penghentian penyidikan yang telah ditetapkan dalam undang-undang.

Penghentian penyidikan terhadap dugaan tindak pidana korupsi dilakukan dengan penerbitan Surat Perintah Penghentian Penyidikan (SP3) oleh pejabat penyidik, apabila dalam kasus tindak pidana korupsi tersebut tidak ditemukannya perbuatan melawan hukum, tidak ditemukan bukti yang kuat dan tidak ditemukannya kerugian keuangan negara (Rumajar, 2014)

\section{METODE PENELITIAN}

Sifat penelitian ini adalah deskriptif, penelitian deskriptif adalah salah satu jenis penelitian yang tujuannya untuk menyajikan gambaran lengkap mengenai gejala sosial atau dimaksudkan untuk eksplorasi dan klarifikasi mengenai suatu fenomena atau kenyataan sosial, dengan jalan mendeskripsikan sejumlah variabel yang berkenaan dengan masalah dan unit yang diteliti (Hadjon, 1998)

Penelitian ini termasuk pada jenis penelitian yuridis empiris. Pendekatan yuridis empiris dilaksanakan untuk mengetahui apakah penghentian penyidikan terhadap tindak pidana korupsi telah sesuai dengan ketentuan yang telah ditetapkan oleh undangundang. Pendekatan yuridis sosiologis bertujuan mengetahui persesuaian pelaksanaan penghentian terhadap tindak pidana korupsi dengan undang-undang (Soekanto, 1984).

Data yang digunakan dalam penelitian ini adalah data primer, yaitu data yang diperoleh langsung dari masyarakat dan didukung dengan data sekunder yaitu data yang diperoleh dari penelitian lapangan. Data primer adalah data yang diperoleh dari hasil penelitian lapangan (field research). Sedangkan data sekunder adalah data diperoleh dari hasil penelitian kepustakaan (library research). Data primer diperoleh dengan mengadakan wawancara dengan pihak yang berkompeten memberikan keterangan pada Ditreskrimsus Polda Sumut terkait dengan permasalahan penelitian. Sedangkan penelitian kepustakaan dilakukan dengan melaksanakan penelitian hukum normatif (studi kepustakaan). Sumber data sekunder terdiri dari bahan-bahan hukum, yang meliputi: a) Bahan hukum primer, yaitu: Undang-Undang Dasar 1945. Undang-Undang Nomor 31 Tahun 1999 Tentang Pemberantasan Tindak Pidana Korupsi jouncto UndangUndang Nomor 20 Tahun 2001 Tentang Perubahan Atas Undang-Undang Nomor 31 Tahun 1999 Tentang Pemberantasan Tindak Pidana Korupsi. Undang-Undang Nomor 8 
Tahun 1981 Tentang Kitab Undang-Undang Hukum Acara Pidana. b). Bahan hukum sekunder, yang memberikan penjelasan mengenai bahan hukum primer, seperti rancangan undang-undang, hasil-hasil penelitian, hasil karya ilmiah, buku-buku dan lain sebagainya. c. Bahan hukum tertier, yakni bahan hukum yang memberikan petunjuk maupun penjelasan terhadap bahan hukum primer dan sekunder, seperti kamus, ensiklopedia, dan seterusnya (Soekanto, 1994).

Memperoleh data yang valid mengenai penghentian penyidikan terhadap tindak pidana korupsi oleh penyidik Polisi, dalam penelitian ini penulis melaksanakan penelitian lapangan di kantor Ditreskrimsus Polda Sumut.

Teknik pengumpulan data dalam penelitian terdiri dari dua jenis, yaitu dengan menggunakan teknik wawancara dan studi dokumen (kepustakaan). Teknik wawancara dilaksanakan guna memperoleh data primer yang bersumber dari penelitian lapangan. Untuk memperoleh data yang valid mengenai permasalahan penelitian, maka diadakan wawancara dengan pihak yang mewakili dan berkompeten pada Kantor Ditreskrimsus Polda Sumut. Selanjutnya juga dilakukan studi dokumen yang merupakan langkah awal dari setiap penelitian hukum, karena penelitian hukum selalu bertolak dari premis normatif. Studi dokumen bagi penelitian hukum meliputi studi bahan-bahan hukum yang terdiri dari bahan hukum primer, bahan hukum sekunder dan bahan hukum tersier (Amiruddin dan Zainal Asikin, 2014)

Analisis data dalam penelitian ini menggunakan analisis data kualitatif. Proses analisis data yang dilakukan dalam penelitian ini meliputi beberapa tahapan, yaitu: a. Analisis data. Analisis data dilakukan semenjak data diperoleh di lapangan. Dari analisa data diperoleh tema dan rumusan hipotesa. b. Reduksi data. Reduksi data merupakan kegiatan proses pengurangan data dan juga penambahan data. Dalam mereduksi data dapat terjadi pengurangan data dan atau penambahan data yang dianggap relevan, sehingga dihasilkan data yang sempurna. c. Penyajian data. Setelah proses reduksi data, tahap selanjutnya adalah penyajian data. Penyajian data merupakan proses pengumpulan informasi yang disusun berdasar kategori atau pengelompokanpengelompokan yang diperlukan. d. Interpretasi data. Setelah melalui tahapan penyajian data, tahap selanjutnya adalah proses pemahaman makna dari serangkaian data yang telah tersaji, dalam wujud yang tidak sekedar melihat apa yang tersurat, namun lebih pada memahami atau menafsirkan mengenai apa yang tersirat di dalam data yang telah disajikan. e. Penarikan kesimpulan/verifikasi. Tahapan terakhir dari proses analisis data adalah penarikan kesimpulan. Tahap ini merupakan proses perumusan makna dari hasil penelitian yang diungkapkan dengan kalimat yang singkat, padat dan mudah difahami.

\section{HASIL DAN PEMBAHASAN}

\section{Pengaturan Penghentian Penyidikan Terhadap Tindak Pidana Korupsi}

Penyidikan suatu istilah yang di maksudkan sejajar dengan pengertian opsporing atau onderzoek (Belanda) dan investigation (Inggris) atau penyiasatan atau siasat (Malaysia) (Hamzah, 2008). Pasal 1 butir 2 KUHAP merumuskan pengertian penyidikan sebagai berikut: 
"Penyidikan adalah serangkaian tindakan penyidik dalam hal dan menurut cara yang diatur dalam undang-undang ini untuk mencari serta mengumpulkan bukti yang dengan bukti itu membuat terang tentang tindak pidana yang terjadi dan guna menemukan tersangkanya". Selanjutnya, Andi Sofyan menjelaskan bahwa, "hakikat penyidikan perkara pidana adalah untuk menjernihkan persoalan, untuk mengejar si pelaku kejahatan, sekaligus menghindarkan orang yang tidak bersalah dari tindakan yang tidak seharusnya" (Sofyan, 2010).

Penyidikan terhadap suatu perkara pidana adakala penyidik menemukan jalan buntu sehingga tidak memungkinkan dilanjutkannya penyidikan terhadap pekara tersebut. Atas dasar pertimbangan tersebut, penyidik diberi kewenangan untuk melakukan penghentian penyidikan sebagaimana diatur dalam Pasal 109 ayat (2) KUHAP.

KUHAP tidak memberikan penjelasan lebih lanjut mengenai penghentian penyidikan, KUHAP hanya menegaskan bahwa penghentian penyidikan dapat dilaksanakan sesuai dengan alasan-alasan yang tercantum didalam Pasal 109 ayat (2), yang menyebutkan: “...penyidik menghentikan penyidikan karena tidak terdapat cukup bukti atau peristiwa tersebut ternyata bukan merupakan tindak pidana atau penyidikan dihentikan demi hukum...”.

Berdasarkan ketentuan Pasal 109 ayat (2), penghentian penyidikan oleh penyidik didasari pada 3 (tiga) alasan, yaitu: tidak terdapat cukup bukti, perbuatan tersebut bukan merupakan tindak pidana dan penyidikan dihentikan demi hukum. Konsekuensi hukum dari penghentian penyidikan adalah diterbitkannya Surat Perintah Penghentian Penyidikan (SP3) (Harahap, 2009).

KUHAP telah mengatur dan menentukan secara limitatif mengenai alasan- alasan atau halhal yang menyebabkan dilakukannya penghentian penyidikan terhadap suatu dugaan tindak pidana. Penghentian penyidikan merupakan kewenangan yang diberikan oleh undang-undang kepada penyidik untuk dipergunakan oleh penyidik sebagai dasar atau alasan melakukan penghentian penyidikan.

Menurut M. Yahya Harahap, bahwa pengaturan dan penggarisan mengenai alasan-alasan penghentian penyidikan didasari pertimbangan agar dalam mempergunakan wewenang penghentian penyidikan, penyidik menguji kepada alasan-alasan yang telah ditentukan (Harahap, 2009). Lebih lanjut, M. Yahya Harahap menjelaskan mengenai beberapa alasan dilakukannya penghentian penyidikan sesuai dengan rumusan Pasal 109 ayat (2) KUHAP, yaitu (Harahap, 2009):

1. Tidak diperoleh bukti yang cukup. Apabila penyidik tidak memperoleh cukup bukti untuk menuntut tersangka atau bukti yang diperoleh penyidik tidak memadai untuk membuktikan kesalahan tersangka jika diajukan ke depan sidang pengadilan, maka berdasarkan pertimbangan tersebut penyidik berwenang untuk melakukan penghentian penyidikan.

2. Peristiwa yang disangkakan bukan merupakan tindak pidana. Apabila hasil penyidikan dan pemeriksaan, penyidik berpendapat bahwa apa yang disangkakan terhadap tersangka bukan merupakan perbuatan pelanggaran dan kejahatan, dalam hal ini penyidik berwenang untuk menghentikan penyidikan.

3. Penghentian penyidikan demi hukum. Penghentian penyidikan atas dasar alasan demi hukum pada pokoknya sesuai dengan alasan-alasan hapusnya hak untuk menuntut dan 
hilangnya hak menjalankan pidana yang diatur dalam Bab VIII KUHP, sebagaimana dirumuskan dalam Pasal 76,77, dan Pasal 78 KUHP.

Penghentian penyidikan demi hukum, terdapat beberapa keadaan yang dijadikan sebagai dasar dilakukannya penghentian penyidikan, diantaranya (Harahap, 2009):

1. Nebis in idem, asas ini menentukan bahwa seseorang tidak dapat lagi dituntut untuk kedua kalinya atas dasar perbuatan yang sama, terhadap mana atas perbuatan itu orang yang bersangkutan telah pernah diadili dan telah diputus perkaranya oleh hakim atau pengadilan yang berwenang serta putusan itu telah memperoleh kekuatan hukum tetap.

2. Tersangka meninggal dunia. Meninggalnya tersangka maka dengan sendirinya penyidikan harus dihentikan. Hal ini sesuai dengan prinsip hukum yang berlaku universal pada abad modern, yakni kesalahan tindak pidana yang dilakukan oleh seseorang adalah menjadi tanggung jawab sepenuhnya dari pelaku yang bersangkutan. Prinsip hukum ini adalah penegasan pertanggungjawaban dalam hukum pidana, yang mengajarkan bahwa tanggung jawab seseorang dalam hukum pidana, hanya ditimpakan kepada si pelaku tindak pidana.

3. Kadaluarsa. Sesuai dengan ketentuan Pasal 78 KUHP, apabila telah dipenuhinya tenggang waktu penuntutan seperti yang diatur dalam Pasal 78 KUHP, dengan sendirinya menurut hukum penuntutan terhadap pelaku tindak pidana tidak lagi boleh dilakukan. Logikanya, jika terhadap seseorang pelaku tindak pidana telah hapus wewenang untuk menuntut di muka sidang pengadilan, tentu percuma melakukan penyidikan dan pemeriksaan terhadap orang itu.

Alasan-alasan dilaksanakannya penghentian penyidikan secara umum sangat mudah dipahami, alasan pertama yaitu tidak terdapat cukup bukti. Oleh karenanya perkara tersebut tidak memungkinkan untuk dilanjutkan pada tahap pemeriksaan di muka persidangan, karena bukti-bukti yang ditemukan dianggap tidak cukup untuk membuktikan kesalahan yang disangkakan pada tersangka.

Alasan kedua, peristiwa tersebut ternyata bukan merupakan tindak pidana. Pada proses penyidikan, adakalanya suatu perbuatan yang awalnya diduga sebagai tindak pidana ternyata dengan alasan-alasan hukum tertentu peristiwa tersebut dianggap bukan sebagai tindak pidana atau perbuatan tersebut merupakan suatu perbuatan pidana, tetapi terdapat alasan pembenar dan alasan penghapus pidana dari perbuatan tersebut.

Sebagai contoh, seorang pemuda di kota Bekasi yang bernama Mohammad Irfan Bahari (MIB), awalnya dianggap sebagai pelaku pembunuhan terhadap IY (korban) berdasarkan laporan AS teman korban. Berdasarkan laporan AS, maka kemudian Polrestabes Metro Bekasi menetapkan MIB sebagai tersangka. Namun, setelah dilakukan proses penyidikan dan pemeriksaan, ternyata faktanya sangat bertolak belakang. IY (korban) dan AS sebelum melakukan perampasan terhadap barang milik MIB dan melakukan ancaman dengan menggunakan celurit (https://www.merdeka.com, berita Kamis, 31 Mei 2018, diakses tanggal 1 Agustus 2019).

Muhammad Irfan yang ketika itu menjadi korban perampokan (begal) melakukan perlawanan terhadap IY dengan menggunakan senjata milik pelaku, kemudian membacok pelaku yang menyebabkan kematian. Perbuatan MIB menurut penyidik Satreskrim Polrestabes Metro Bekasi bukan merupakan suatu 
tindak pidana, karena apa yang dilakukan oleh MIB adalah tindakan pembelaan diri. Berdasarkan pertimbangan tersebut, penyidik melakukan penghentian penyidikan dan membebaskan tersangka sekaligus memberi penghargaan terhadap Muhammad Irfan karena telah berhasil melumpuhkan begal (https://www.merdeka.com, berita Kamis, 31 Mei 2018, diakses tanggal 1 Agustus 2019).

Alasan ketiga, penghentian penyidikan dilaksanakan demi hukum. penghentian penyidikan demi hukum pada pokoknya sesuai dengan alasan-alasan hapusnya hak menuntut dan hilangnya hak menjalankan pidana yang diatur dalam Bab VIII KUHP, sebagaimana diatur pada Pasal 76, 77, dan Pasal 78 dan seterusnya. Penghentian penyidikan demi hukum, diantaranya adalah: nebis in idem, tersangka meninggal dunia, dan karena kadaluarsa (Harahap, 2009).

Berdasarkan uraian di atas, dapat dipahami bahwa penghentian penyidikan terhadap suatu perkara pidana merupakan kewenangan yang diberikan oleh undang-undang kepada penyidik, yaitu suatu kewenangan baru yang diberikan kepada penyidik sebagaimana ditentukan didalam KUHAP. Dengan demikian, dapat dikatakan bahwa kewenangan penghentian penyidikan merupakan kewenangan atribusi, yaitu suatu kewenangan yang didasari pada legitimasi yang sah dengan diaturnya kewenangan tersebut dalam undangundang.

\section{Implikasi Yuridis Terhadap Penghentian Penyidikan Terhadap Tindak Pidana Korupsi}

Implikasi yuridis bermakna pula sebagai akibat hukum. Akibat hukum merupakan suatu akibat dari tindakan yang dilakukan, untuk memperoleh suatu akibat yang diharapkan oleh pelaku hukum. Akibat yang dimaksud adalah akibat yang diatur oleh hukum, sedangkan tindakan yang dilakukan merupakan tindakan hukum yaitu tindakan yang sesuai dengan hukum yang berlaku (Soeroso, 2010).

Achmad Ali, menjelaskan bahwa akibat hukum adalah suatu akibat yang ditimbulkan oleh hukum, terhadap suatu perbuatan yang dilakukan oleh subjek hukum (Ali, 2010). Adapun perbuatan hukum adalah setiap perbuatan subjek hukum (manusia atau badan hukum) yang akibatnya diatur oleh hukum dan karena akibat tersebut dapat dianggap sebagai kehendak dari yang melakukan hukum (Soeroso, 2010).

Berdasarkan pengertian akibat hukum yang dikemukakan para sarjana tersebut di atas, dapat dipahami bahwa perbuatan hukum adalah suatu perbuatan yang dilakukan oleh subjek hukum (manusia atau badan hukum), perbuatan mana dapat menimbulkan suatu akibat yang dikehendaki oleh yang melakukannya. Jika perbuatan itu akibatnya tidak dikehendaki oleh yang melakukan atau salah satu di antara yang melakukannya, maka perbuatan itu bukan perbuatan hukum. Oleh karena itu, kehendak dari subjek hukum (manusia atau badan hukum) yang melakukan perbuatan itu menjadi unsur pokok dari perbuatan tersebut.

Lebih jelas lagi bahwa akibat hukum adalah segala akibat yang terjadi dari segala perbuatan hukum yang dilakukan oleh subyek hukum terhadap obyek hukum atau akibatakibat lain yang disebabkan karena kejadian-kejadian tertentu oleh hukum yang bersangkutan telah ditentukan atau dianggap sebagai akibat hukum. Penghentian penyidikan merupakan 
suatu keputusan yang diambil atau dijatuhkan oleh pejabat penyidik Polisi. Dalam hal penyidikan terhadap tindak pidana korupsi oleh penyidikan diputuskan untuk dilakukan penghentian penyidikan, maka akan memiliki implikasi terhadap proses hukum lebih lanjut terhadap perkara tindak pidana korupsi itu, yaitu terhentinya proses penyidikan sampai ditemukan atau adanya cukup bukti yang mendukung untuk dilakukannya kembali proses penyidikan (Wawancara dengan Fahriza, selaku Penyidik Tipikor di Ditreskrimsus Polda Sumut, pada tanggal 6 Mei 2019).

Adanya penghentian penyidikan sebagai keputusan yang telah ditetapkan oleh pejabat penyidik Polisi terhadap penyidikan suatu perkara tindak pidana korupsi, maka proses hukum terhadap perkara tersebut akan terhenti. Terhentinya proses hukum terhadap perkara tersebut terdapat dua kemungkinan, yaitu bisa jadi untuk waktu selamanya karena tidak terdapat buktibukti pendukung untuk melakukan penyidikan kembali atau bisa pula dalam waktu sementara, karena adanya bukti atau alat bukti baru yang mendukung dilakukannya kembali proses penyidikan oleh penyidik (Wawancara dengan Fahriza, selaku Penyidik Tipikor di Ditreskrimsus Polda Sumut, pada tanggal 6 Mei 2019).

Penghentian suatu penyidikan tindak pidana korupsi tentunya akan menimbulkan implikasi hukum, yaitu terhentinya proses hukum lebih lanjut terhadap perkara tersebut, yaitu tidak dilanjutkannya proses hukum berupa pelimpahan perkara dari penyidik ke penuntut umum.

Terhentinya proses hukum tersebut dapat bersifat selamanya, dan dapat pula bersifat sementara. Proses hukum lebih lanjut terhadap perkara tindak pidana korupsi yang oleh penyidik Polisi diterbitkan Surat Perintah Penghentian Penyidikan, dapat bersifat selamanya jika ternyata bukti-bukti terhadap perkara tindak pidana korupsi tersebut tidak juga ditemukan setelah diterbitkannya surat perintah penghentian penyidikan.

Penghentian penyidikan yang didasari pada alasan meninggalnya tersangka, maka penghentian penyidikan tersebut bersifat selamanya (permanen). Artinya, proses hukum terhadap perkara tersebut tidak lagi akan diproses lebih lanjut. Demikian pula penghentian penyidikan yang didasari pada alasan nebis in idem, dengan terbitnya surat perintah penghentian penyidikan karena alasan tersebut, maka proses hukum tidak akan dapat dilanjutkan atau dihentikan.

Penghentian penyidikan terhadap perkara tindak pidana korupsi tidak saja berimplikasi pada terhentinya proses hukum terhadap suatu perkara, tetapi juga menimbulkan konsekuensi hukum gugatan praperadilan dari pihak yang merasa dirugikan terkait dengan diterbitkannya SP3 tersebut. Karenanya, penyidik Polisi dalam menentukan keputusan penghentian penyidikan harus benar-benar memiliki dasar hukum yang kuat sesuai dengan ketentuan yang telah dirumuskan dalam

Pasal 109 ayat (2) KUHAP. Dengan demikian, maka keputusan penghentian penyidikan nantinya dapat dipertanggungjawabkan, apabila ada gugatan praperadilan yang diajukan oleh pihak-pihak yang berkepentingan (Wawancara dengan Fahriza, selaku Penyidik Tipikor di Ditreskrimsus Polda Sumut, pada tanggal 6 Mei 2019).

Gugatan Pra-peradilan menurut Pasal 1 angka 10 KUHP berkenaan dengan kewenangan dari penyidik, mengenai: 1 . Sah atau tidaknya suatu penangkapan dan atau penahanan atas 
permintaan tersangka atau keluarhnya atau pihak lain atas kuasa tersangka; 2. Sah atau tidaknya penghentian penyidikan atau penghentian penuntutan atas permintaan demi tegaknya hukum dan keadilan; 3. Permintaan ganti kerugian atau rehabilitasi oleh tersangka atau keluargnya atau pihak lain atas kuasanya yang berperkara tidak diajukan ke pengadilan.

Pra-peradilan sebagai salah satu lembaga baru dalam dunia peradilan Indonesia, hal mana mempunyai ciri dan eksistensi sebagai berikut (Wawancara dengan Fahriza, selaku Penyidik Tipikor di Ditreskrimsus Polda Sumut, pada tanggal 6 Mei 2019): 1. Pra-peradilan berada dan merupakan satu kesatuan yang melekat pada pengadilan negeri, dan sebagai lembaga pengadilan, pra-peradilan hanya dapat dijumpai di tingkat pengadilan negeri sebagai satuan tugas yang tidak terpisahkan dari pengadilan negeri; 2 . Pra-peradilan bukan berada di luar atau di samping maupun sejajar dengan pengadilan negeri, tetapi hanya merupakan bagian atau divisi dari pengadilan negeri; 3. Urusan administratif yudisial, personil, peralatan, dan finansial bersatu dengan pengadilan negeri, dan berada di bawah pimpinan dan pengawasan serta pembinaan Ketua Pengadilan Negeri; 4. Masalah tata laksana fungsi yustisialnya merupakan bagian dari fungsi yustisial pengadilan negeri itu sendiri.

Eksistensi pra-peradilan dalam proses penegakan hukum bertujuan untuk tegaknya hukum dan memberikan perlindungan hak asasi manusia, yakni hak asasi tersangka dalam tingkat penyidikan. Jadi pada prinsipnya tujuan utama dari pelembagaan pra-peradilan adalah untuk melakukan pengawasan secara horizontal atas segala tindakan upaya paksa yang dilakukan oleh penyidik atau penuntut umum kepada tersangka selama dalam pemeriksaan penyidikan, agar tindakan yang dilakukan itu tidak bertentangan dengan ketentuan undangundang yang berlaku. (Sofyan, 2010)

Objek pemeriksaan pra-peradilan sesuai dengan ketentuan Pasal 77 KUHAP KUHAP meliputi: 1) sah atau tidaknya penangkapan, 2) sah atau tidaknya penahanan, 3) sah atau tidaknya penghentian penyidikan, 4) sah atau tidaknya penghentian penuntutan, 5) sah atau tidaknya ganti kerugian dan atau rehabilitasi bagi seorang yang perkara pidananya dihentikan pada tingkat penyidikan atau penuntutan. Ditetapkannya lima objek praperadilan tersebut karena sesuai dengan asas legalitas untuk menjamin kepastian hukum.

Pasca Putusan Mahkamah Konstitusi Nomor 21/PUU-XII/2014, atas permohonan judicial review Pasal 1, Pasal 2, Pasal 1 angka 14, Pasal 17, Pasal 21 ayat (1), Pasal 77 huruf a, Pasal 156 ayat (2) KUHAP yang diangggap telah menimbulkan kerugian hak konstitusional dari pemohon (Putusan Mahkamah Kontitusi Nomor 21 /PUU-XII/2014). Putusan Mahkamah konstitusi Nomor 21/PUU-XII/2014, telah memaksukkan penetapan tersangka sebagai objek pra peradilan. Meskipun di dalam pengambilan putusan tersebut terjadi perbedaan pendapat (dissenting opinion) diantara para hakim Mahkmah.

Berkaitan dengan subjek hukum, yang termasuk dalam subjek hukum praperadilan adalah setiap orang yang dirugikan. Untuk sah atau tidaknya penghentian penyidikan atau penuntutan dapat diajukan oleh penyidik atau penuntut umum atau pihak ketiga yang berkepentingan kepada ketua pengadilan negeri dengan menyebutkan alasannya yaitu untuk menegakkan hukum, keadilan dan kebenaran melalui sarana pengawasan.

Berkenaan dengan penghentian penyidikan oleh penyidik Polisi, maka terdapat kemungkinan adanya pengajuan pra-peradilan oleh penuntut umum dan pihak ketiga yang 
berkepentingan. Hal ini sesuai dengan ketentuan Pasal 80 KUHAP, yang menyatakan: "permintaan untuk memeriksa sah atau tidaknya suatu penghentian penyidikan oleh penyidik, maka penuntut umum atau pihak ketiga yang bekepentingan yang berhak mengajukan permintaan pemeriksaan tentang sah atau tidaknya penghentian penyidikan oleh penyidik, kepada ketua pengadilan negeri dengan menyebut alasannya. Dengan demikian, dapat dipahami bahwa keputusan melaksanakan penghentian penyidikan oleh penyidik Polisi dalam penyidikan terhadap tindak pidana korupsi dapat berimplikasi hukum adanya pengajuan pra-peradilan oleh penuntut umum atau oleh pihak ketiga yang berkepentingan, seperti: pihak LSM yang melaporkan dugaan dari tindak pidana korupsi.

\section{Hambatan Dalam Pelaksanaan Penghentian Penyidikan Terhadap Tindak Pidana Korupsi}

Hambatan Struktur Hukum. Sistem peradilan pidana menentukan lembaga-lembaga penegak hukum yang saling bekerja mendukung satu sama lain, yaitu: Penyidik (Kepolisian), Penuntut Umum (Kejaksaan), Pengadilan (Hakim), Lembaga Pemasyarakatan dan Advokat. Seluruh struktur hukum tersebut saling bekerja dan mendukung antara satu sama lain untuk mencapai tujuan dari sistem peradilan pidana (Atmasasmita, 2012).

Struktur adalah pola yang menunjukkan tentang bagaimana hukum dijalankan menurut ketentuan formalnya. Undang-undang telah menentukan bahwa dalam penyidikan tindak pidana korupsi terdapat tiga lembaga yang berwenang sebagai penyidik atau melakukan penyidikan, yaitu Kepolisian, Kejaksaan dan KPK (Larifah, 2012). Kewenangan penyidik Polisi dalam melakukan penyidikan terhadap tindak pidana korupsi mengacu pada ketentuan yang diatur dalam KUHAP dan Undang-Undang Polri.

Penyidik Polisi sebagai institusi penegak hukum yang berwenang melakukan penyidikan terhadap tindak pidana korupsi masih mengalami banyak kendala dalam proses penegakan hukum, termasuk penegakan hukum terhadap perkara tindak pidana korupsi. Kendala yang dialami oleh penyidik Polisi dalam penegakan hukum terhadap perkara korupsi diantaranya adalah kurangnya jumlah penyidik yang memiliki kualitas sumber daya manusia yang mumpuni di bidang penindakan dan penegakan hukum terhadap perkara tindak pidana korupsi.58

Hambatan Budaya Hukum. Kendala lainnya yang dihadapi oleh institusi Polri sebagai penegak hukum adalah rendahnya kepercayaan (trust) masyarakat terhadap institusi Polri. Berbagai rumor beredar di tengah masyarakat menunjukkan rendahnya kepercayaan masyarakat terhadap institusi Polri. Hal ini sangat wajar terjadi, karena insitusi Polri merupakan garda terdepan dalam kancah penegakan hukum di Indonesia. Aparat penegak huku,m khususnya penyidik dalam melakukan proses penegakan hukum tentunya menemukan berbagai hambatan- yang mempengaruhi jalannya proses penegakan hukum. Secara umum, hambatan yang ditemukan penyidik dalam melakukan penghentin penyidikan dapat dibedakan kedalam dua jenis, yaitu hambatan internal maupun ekternal.

Penghentian Penyidikan terhadap perkara korupsi belakangan ini telah mengundang kontroversi dan perdebatan serta menciptakan persepsi yang cenderung negatif terhadap kinerja dan citra aparat penegak hukum, khususnya penyidik. Penerbitan Surat Perintah 
Penghentian Penyidikan selalu mendapat respon negatif dari masyarakat. Adanya tudingan dari masyarakat bahwa penegak hukum tidak serius dalam menyelesaikan berbagai kasus tindak pidana korupsi. Bahkan, sebagian masyarakat berasumsi bahwa penyidik telah disuap, sehingga tidak meneruskan penyidikan terhadap perkara tindak pidana korupsi tersebut (https://www.hukumonline.com, diakses tanggal 2 Agustus 2019).

Di mata masyarakat yang menghendaki agar pelaku tindak pidana korupsi diproses secara hukum dan dikenai hukuman yang seadil-adilnya, pemberian Surat Perintah Penghentian Penyidikan dianggap sebagai tindakan yang merusak harapan masyarakat dalam upaya pemberantasan korupsi (https://www.hukumonline.com, diakses tanggal 2 Agustus 2019).

Praktiknya, terungkap bahwa penyidik sangat jarang menggunakan alasan tidak cukup bukti. Alasan penyidik enggan menggunakan alasan ini ialah mencegah timbulnya kesan (pada atasan yang berwenang yang berwenang menilai kinerja mereka atau pelapor) bahwa mereka tidak bekerja maksimal dalam mencari dan menemukan alat bukti. Alhasil banyak perkara kemudian, alih-alih diSP3-kan karena kurang bukti, seolah-olah dibiarkan (digantung). Istilah yang biasa digunakan adalah di peti eskan (ice box). Istilah ice box dikenal juga dengan cold case yang bermakna bahwa kasus dingin karena tidak diteruskan dan tidak jelas hasil akhir proses penyelesaiannya (Komisi Kepolisian Nasional, 2015).

Di sini perlu untuk memberikan kesadaran hukum bagi masyarakat mengenai mekanisme penghentian penyidikan dan implikasi hukum dari penghentian penyidikan. Dengan adanya kesadaran hukum masyarakat, maka akan tercipta keserasian di dalam penegakan hukum. Di mana keputusan penyidik dalam menetapkan penghentian penyidikan terhadap tindak pidana korupsi tidak selalu dipandang buruk oleh masyarakat, melainkan merupakan suatu kewenangan yang diberikan oleh undang-undang demi terciptanya keadilan, kepastian dan kemanfaatan hukum.

Berdasarkan faktor-faktor tersebut di atas, dapatlah diidentifikasi beberapa hal yang menjadi hambatan bagi penyidik Polisi di Ditreskrimsus Polda Sumut terkait dengan pelaksanaan kewenangan penghentian penyidikan oleh Kepolisian, yaitu:

1. Kendala internal. Kendala internal penyidik Polisi di Ditreskrimsus Polda Sumut dalam melaksanakan kewenangan penghentian penyidikan terhadap perkara tindak pidana korupsi, adalah masih rendahnya sumber daya manusia, baik itu dilihat dari kuantitas maupun kualitasnya. Personel penyidik Ditreskrimsus Polda Sumut saat ini masih mengalami kekurangan personel penyidik yang memiliki kemampuan yang mumpuni di bidang hukum terkait dengan penanganan dan penyidikan perkara tindak pidana korupsi.

Selain itu, kendala lain yang dihadapi adalah masih kurangnya sarana dan prasana dalam proses penegakan hukum perkara tindak pidana korupsi, misalnya anggaran dalam melakukan penyidikan terhadap pekara tindak pidana korupsi, yang belum memungkinkan untuk terlaksananya penyidikan yang efektif dan efisien (Wawancara dengan Fahriza, selaku Penyidik Tipikor di Ditreskrimsus Polda Sumut, pada tanggal 6 Mei 2019.)

Hambatan lainnya, adalah kurangnya koordinasi dengan pihak atau instansi terkait. Dalam penyelidikan dan penyidikan tindak pidana korupsi, pihak penyidik tentunya harus menjalin kerjasama dengan berbagai pihak, seperti: BPK, Kejaksaan dan juga instansi terkait lain 
(Wawancara dengan Fahriza, selaku Penyidik Tipikor di Ditreskrimsus Polda Sumut, pada tanggal 6 Mei 2019).

Penghentian penyidikan terhadap tindak pidana korupsi yang dilakukan oleh penyidik Kepolisian, maka sebelumnya pihak penyidik terlebih dahulu memberitahukan kepada Kejaksaan mengenai telah dimulainya penyelidikan terhadap suatu perkara. Dengan adanya pemberitahuan tersebut, maka akan mewujudkan kesatuan persepsi terhadap perkara yang sedangkan dilakukan penyelidikan dan penyidikan. Jika ternyata penyidik menghentikan penyelidikan, maka penyidik wajib memberitahukan perkembangan penyelidikan tersebut kepada Kejaksaan, dengan menyampaikan alasan-alasan yang patut dan sesuai dengan undangundang.

Prakteknya, ternyata belum ada kesatuan persepsi antar lembaga penegak hukum, sehingga ada kemungkinan penghentian penyidikan yang dilakukan penyidik diajukan praperadilan oleh Kejaksaan. Hal ini tentunya menjadi hambatan tersendiri bagi penyidik dalam memutuskan penghentian penyidikan.

2. Kendala eksternal. Secara hukum, penghentian penyidikan oleh penyidik Polisi membuka peluang untuk diajukannya gugatan pra-peradilan dari pihak yang berkepentingan terhadap sah tidaknya penghentian penyidikan tersebut (Eddyono, 2014.). Misalnya, gugatan pra-peradilan dari Kejaksaaan maupun pihak ketiga. Meskipun sangat jarang terjadi, namun penghentian penyidikan oleh penyidik dapat diajukan pra-peradilan oleh Kejaksaan mengenai sah tidaknya penghentian penyidikan yang dilakukan oleh penyidik Kepolisian. Selain itu, penghentian penyidikan yang dilakukan penyidik terhadap perkara korupsi seringkali dianggap masyarakat sebagai bentuk penyimpangan yang dilakukan oleh penyidik Polisi. Di mata masyarakat yang menghendaki agar pelaku tindak pidana korupsi diproses secara hukum dan dikenai hukuman yang seadil-adilnya, Penghentian Penyidikan dianggap sebagai tindakan yang merusak harapan masyarakat dalam upaya pemberantasan korupsi (Yunto, 2010).

\section{SIMPULAN}

Pengaturan penghentian penyidikan terhadap tindak pidana korupsiberdasarkan KUHAP didasari pada tiga alasan, yaitu karena tidak terdapat cukup bukti, karena perbuatan tersebut tidak termasuk atau bukan merupakan tindak pidana karena batal demi hukum. Implikasi yuridis terhadap penghentian penyidikan terhadap tindak pidana korupsi. Dalam hal penghentian penyidikan dikarenakan tidak cukup bukti, maka penghentian penyidikan dapat bersifat sementara ataupun selamanya. Sedangkan dalam hal penghentian penyidikan dikarenakan perbuatan itu tidak merupakan sebagai perbuatan pidana, maka penghentian bersifat selamanya. Kemudian, jika alasan penghentian penyidikan dikarenakan demi hukum, maka penghentian penyidikan juga bersifat selamanya. Hambatan dalam pelaksanaan penghentian penyidikan terhadap tindak pidana korupsi adalah dipengaruhi oleh dua faktor, yaitu faktor internal dan eskternal. Faktor internal diantaranya kurangnya SDM dari penyidik yang ada di Ditreskrimsus Polda Sumut. Sedangkan kendala eksternal, yaitu asumsi masyarakat bahwa SP3 sarat akan penyimpangan. 


\section{DAFTAR PUSTAKA}

Chazawi, A. (2001). Pelajaran Hukum Pidana Bagian I, Jakarta; Raja Grafindo.

Hamzah, A, (2005). Pemberantasan Korupsi Melalui Hukum Pidana Nasional Dan Internasional, Jakarta; Rajawali Press.

Ali, A. (2008) Menguak Tabir Hukum, Jakarta; Prenada Kencana Media Group.

Alfitra, (2012). Hapusnya Hak Menuntut Menjalankan Pidana, Depok; Raih Asia Sukses.

Sofyan, A (2013), Hukum Acara Pidana Suatu Pengantar, Prenada Kencana Media Group, Jakarta.

Amiruddin dan Asikin, Z. (2014), Pengantar Metode Penelitian Hukum, Rajawali Pers, Jakarta, 2014.

Sunggono, B. dan Harianto, A. (2009), Bantuan Hukum Dan Hak Asasi Manusia, Mandar Maju, Bandung.

Handoyo, B.H.C, (2015). Hukum Tata Negara Indonesia, Cahaya Atma Pustaka, Yokyakarta.

Cahyono, (2019). Model Mediasi Penal Dalam Penanggulangan Konflik Kekerasan Carok Masyarakat Madura Berdasarkan Local Wisdom, Deepublihs, Yokyakarta.

Darmodiharjo, D. \& Shidarta (1995). Pokok-pokok Filsafat Hukum, Apa dan Bagaimana Filosafat Hukum Indonesia, Gramedia, Jakarta,

Mansur, D.M.A. \& Gultom, E, (2009). Cyber Law, Aspek Hukum Teknologi Informasi, Refika Aditama, Bandung.

Samosir, D. (2013), Segenggam tetang Hukum Acara Pidana, Bandung; Nuansa Aulia.

Danil, E. (2011). KORUPSI, Konsep, Tindak Pidana dan Pemberantasannya, Rajawali Pers, Jakarta, 2011.

Hartanti, E. (2012). Tindak Pidana Korupsi, Edisi Kedua, Sinar Grafika, Jakarta

Mulyadi, L, (2013). Pembalikan Beban Pembuktian Tindak Pidana Korupsi, Alumni, Bandung, 2013.

Harahap, M.Y. (2009). Penyidikan dan Penuntutan, Sinar Grafika, Jakarta, 2009.

Hadjon, P.M. (1998). Penataan Hukum Administrasi, Fakultas Hukum Unair, Surabaya, 1998.

Atmasasmita, R, (2012) Sistem Peradilan Pidana Kontemporer, Prenada Kencana Media Group, Jakarta.

Soekanto, S. (1984), Penelitian Hukum Normatif Suatu Tinjauan, Rajawali Pers, Jakarta, 1984.

Soekanto, S. (1991), Kegunaan Sosiologi hukum Bagi Kalangan Hukum, Citra Aditya Bakti, Bandung, 1991.

Soeroso, (2010). Pengantar Ilmu Hukum, Jakarta; Rajawali Pers.

Shidarta, (2010) Reformasi Peradilan dan Tanggung Jawab Negara, Komisi Yudisial, Jakarta.

Rumajar, J.O. (2014)., Alasan Penghentian Penyidikan Suatu Tindak Pidana Korupsi, Jurnal Lex Crimen Vol. III/No. 4/Agus- Nov/2014. Fakultas Hukum Unsrat.

Larifah, M. (2012), Legalitas Kewenangan Jaksa Dalam Penyidikan Tindak Pidana Korupsi. Jurnal Negara Hukum Vol. 3, No. 1, Juni 2012.

Hadjon, P.M. (1994), Fungsi Normatif Hukum Administrasi dalam Mewujudkan Pemerintahan yang Bersih, Pidato Penerimaan jabatan Guru Besar dalam Ilmu Hukum pada Fakultas Hukum Universitas Airlangga, Surabaya,.

Undang-Undang Dasar Negara Republik Indonesia Tahun 1945 Amandemen ke- IV.

Undang-Undang Nomor 8 Tahun 1981 Tentang Kitab Undang-Undang Hukum Pidana.

Undang-Undang Nomor 31 Tahun 1999 Tentang Pemberantasan Tindak Pidana Korupsi jouncto UndangUndang Nomor 20 Tahun 2001 Tentang Perubahan Atas Undang-Undang Nomor 31 Tahun 1999 Tentang Pemberantasan Tindak Pidana Korupsi.

Peraturan Pemerintah Nomor 27 Tahun 1983 tentang Pelaksanaan Kitab Undang- Undang Hukum Acara Pidana.

Peraturan Pemerintah Nomor 58 Tahun 2010 yang merupakan perubahan atas Peraturan Pemerintah Nomor 27 Tahun 1983 Tentang Peraturan Pelaksanaan Kitab Undang-Undang Hukum Acara Pidana.

PerKap Nomor 14 Tahun 2012 Tentang Manajemen Penyidikan.

Surat Edaran Kapolri Nomor 7 Tahun 2018 Tentang Penghentian Penyidikan.

Aminoer Rasyid, Kasus OTT Bupati Pakpak Barat, Pemkab Telah Kembalikan Uang, berita 21 Nov 2018, melalui: https://nasional. sindonews.co, diakses tanggal 2 Agustus 2019.

Baringin Lumban Gaol, Polda Sumut Bantah OTT Bupati Pakpak Barat Terkait Penghentian Kasus Isterinya, melalui: https://www.gatra. com, diakses tanggal 2 Agustus 2019.

Emerson Yunto, Mencermati Pemberian Kasus SP3 Korupsi, melalui: https://www.hukumonline.com, diakses tanggal 2 Agustus 2019.

Lizza Egeham, KPK Telusuri Suap Bupati Pakpak Barat Terkait Kasus Sang Isteri, berita 19 Nov 2018, melalui: https://www.liputan6.co.id, diakses tanggal 2 Agustus 2019.

Nanda Perdana Putra, Tewaskan Perampiok Dibekasi, Irfan diberi penghargaan Polisi, melalui: https://www.merdeka.com, berita Kamis, 31 Mei 2018, diakses tanggal 1 Agustus 2019. 